\title{
MEAT HYGIENE PRACTICES AMONG MEAT SELLERS IN DHARAN MUNICIPALITY OF EASTERN NEPAL
}

\author{
Bhattarai $J^{1^{*}}$, Badhu $A^{2}$, Shah $T^{2}$, Niraula $S R^{3}$
}

\section{Affiliation}

1. Lecturer, Community Health Nursing, Nobel Medical College Teaching Hospital, Biratnagar Nepal

2. Professor, Department of Community Health Nursing College of Nursing, B. P. Koirala Institute of Health Sciences, Dharan, Nepal

3. Professor, School of Public Health and Community Medicine, B.P. Koirala Institute of Health Sciences, Dharan, Nepal

\section{ARTICLE INFO \\ Article History \\ Received : 11 June, 2017 \\ Accepted : 15 June, 2017 \\ Published : 30 August, 2017}

(C) Authors retain copyright and grant the journal right of first publication with the work simultaneously licensed under Creative Commons Attribution License CC - BY 4.0 that allows others to share the work with an acknowledgment of the work's authorship and initial publication in this journal.

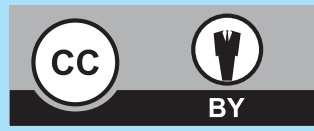

ORA 28

* Corresponding Author

Jamuna Bhattarai

Lecturer, Community Health Nursing

Nobel Medical College Teaching Hospital, Biratnagar Nepal Email: jgbhattarai@gmail.com

\section{Citwation}

Bhattarai J, Badhu A, Shah T, Niraula SR. Meat Hygiene Practices among Meat Sellers in Dharan Municipality of Eastern Nepal. BJHS 2017;2 (2)3:184-190

\section{ABSTRACT \\ Introduction}

Eating the meat derived from animals suffering from zoonotic diseases or contaminated with meat borne bacteria cause infection or intoxication and grave danger to both the handler and consumer causing morbidity and mortality.

\section{Objective}

The study aims to assess the meat hygiene practices among meat sellers in Dharan City of Eastern Nepal.

\section{Methodology}

A descriptive cross sectional study was carried in all meat shops registered in Dharan from December 2013 to December 2014. A total of 125 meat shops, which were registered in Dharan Municipality, Dharan Mashu Baybasashi Prabadhi Sang and Dharan Mashu Baybasashi Sangh were enrolled. Checklist and semi structured interview schedule were used to assess the hygiene practices of meat shops. Data were analyzed by using descriptive as well as inferential statistics.

\section{Results}

This study revealed that practice of meat inspection, antemortem and post-mortem examination of animals/carcass were not seen and separate slaughterhouse was not made. Only few $(19 \%)$ of the respondents had practice of washing hands before and after touching of meat. Near about half $(48.8 \%)$ of the meat sellers reported that they do not wear body protective material/device while selling, $43 \%$ of them had practice of selling meat of infectious, emaciated and pregnant animals as well as with suckling offspring. None of them met all the criteria, whereas more than half met the criteria up to $50 \%$ set by meat act. Education, amount of selling and type of meat was significantly associated $(p<0.001)$ with hygiene practices.

\section{Conclusion}

The study concludes that hygiene practices of all the meat shops in Dharan Municipality was not found to be satisfactory. Most of the criteria set by authorities remained unmet. Only few meat shops were maintaining the scientific handling and hygienic practices. Study revealed that education and type of meat were significantly associated with meat hygiene practice. Concerned authorities should be aware to improve the quality of meat hygiene practice.

\section{KEY WORDS}

Meat hygiene, meat shop, meat seller 


\section{INTRODUCTION}

Food-borne pathogens are the leading cause of illness and death in developing countries, costing billions of dollars in medical care with social costs. Contaminated raw meat is one of the main sources of food-borne illnesses. The risk of the transmission of zoonotic infections is also associated with contaminated meat. ${ }^{1}$

During the slaughtering operations performed in slaughter places with inadequate sanitation and unskilled staff, contamination frequently occurs from dirt, unclean water, intestinal contents or from dirty knives, hands or clothing of butcher. ${ }^{1}$ These factors all lead to infection of meat, bacterial multiplication and possible toxin production. Lack of basic facilities, cross-contamination by insects, flies and numerous other unhygienic factors contribute to the danger of consumer infection. ${ }^{2}$ There is strong evidence that in many developing countries conditions of slaughter houses and current meat handling practices contribute greatly to the spread of zoonotic diseases. Similarly lack of ante-mortem, postmortem examination cannot identify the diseased animals so that zoonotic diseases transmits easily by handling raw meat, blood and eating diseased meat. ${ }^{2}$ WHO estimates that cysticercosis affects some 50 million people worldwide and in endemic areas, causes some 50000 deaths. ${ }^{1}$

In Nepal, minimum hygienic standard defined by national and international laws and regulations is not followed during the meat production and marketing chain. ${ }^{3}$ The zoonotic pork tapeworm, Taenia solium, is becoming an increasing problem in Nepal. ${ }^{4}$ In Dharan, survey of 31 meat shops showed that the hygiene condition of meat sold was found unsatisfactory. ${ }^{5}$ Hospital evidence shows that 5 Cysticercosis, 16 cases of Echinococcosis/Hydatidosis and 23 cases of Epilepsy were treated in B. P. Koirala Institute of Health Sciences, Dharan in $2013 .^{6}$

However, the magnitude of public health concern and significance of meat-borne diseases in developing countries is often underestimated. The frequency, intensity and prevalence of such diseases has dramatically increased in developing countries. ${ }^{2}$ The authorities of these countries are mostly aware of the bad situation, in some cases they have tried for the modernization and development of slaughter houses and revised their meat-handling procedure. However, these plans usually apply in urban areas where as most of the slaughtering still occurs in rural areas where there is an urgent need for improvement in meet and slaughter hygiene. ${ }^{2}$ For regulating and managing the meat sector, Government of Nepal passed Slaughterhouse and Meat Inspection Act (SMIA) in 1999. Since then, Department of
Livestock Services (DLS) has made many efforts to implement the Act and manage the meat business in Kathmandu city and other large cities. In spite of such efforts, consumers are compelled to eat poor quality and diseased meat, public are bound to live with the risk of various zoonotic-meat borne diseases; and various cases of frauds are evident from time to time. ${ }^{7}$

Lack of slaughter house, lack of proper infrastructure in the slaughtering places and meat shops, shortage of adequately trained personnel, improper slaughtering and handling of meat and the most importantly the lack of meat inspection and examination, have caused cumulative effect on improper meat hygiene in Dharan Municipality. Meat products coming from such conditions are often deteriorated due to bacterial infection or contamination, which may cause food poisoning or diseases in consumers. ${ }^{8}$

Average meat consumption per person in Dharan is $13 \mathrm{~kg}$ compared to national $9 \mathrm{~kg}$ per person consumption. ${ }^{5}$ This shows high meat consumption by the people living in Dharan and also transportation of meat (especially pork) from Dharan to other places is popular. The identification of magnitude meat health practice problem is important for designing the preventive program to address public health problem related to meat-borne diseases with medical and social costs related to it.

The study is therefore, focused to assess the hygienic condition of the presently growing meat business of Dharan, particularly meat hygiene practice at meat shop in Dharan Municipality.

\section{METHODOLOGY}

This study is based on descriptive cross sectional study design. All the meat sellers who were registered either in Dharan Sub-Metropolitan city or local meat organization were enrolled in study sample. All together the registered 125 meat shops were found active at present in Dharan Sub-Metropolitan city. Self-prepared checklist and semi-structured interview schedule was developed based on Slaughterhouse and Meat Inspection Regulation Act (SIMA) 2001 A. D. (2057 B.S) which also meet the criteria of WHO Guidelines for sloughter house in developing countries. The instrument consisted of five sections: (1) Socio-Demographic Characteristics (2) Ante-mortem and post-mortem examination (3) Structure of meat shop (4) Terms and conditions followed by seller (5) Personnel hygiene of meat seller. Structure of meat shop included, wall, roof, floor and basic structural facility according to act. Terms and conditions included provisions, requirements and rules, for conducting the slaughtering and meat selling business 
according to SIMA. All the demographic variable were independent variable and meat hygiene practice was dependent variable. Tool was pretested among 14 meat sellers, and necessary modification was done. Content validity was done with 7 subject experts. Demographic information of the subjects was obtained first and then the slaughtering places and meat shop were observed and meat sellers were interviewed by the researcher herself. Privacy and confidentiality was maintained during study. All the subjects involved were more than 18 years old. Data was collected from December 2013 to December 2014.

Study protocol was approved by Institutional Ethical Review Committee of B. P. Koirala Institute of Health Science (BPKIHS), Dharan Nepal, which is an authorized institution of Nepal Health Research Council Nepal. After taking permission from BPKIHS, Dharan Municipality Office, Veterinary Office, local meat organizations data collection was started. The subjects were explained regarding the objectives of the study and informed verbal consent was obtained from each subject before data collection. Confidentiality of the data was maintained and assurance of data for not disclosing was provided prior to study.

\section{Data Processing and Analysis}

The data was entered into Microsoft Excel 2007 and analyzed in SPSS 17.0. Mean and standard deviation were calculated. In three domains, scoring was given to each characteristic as 1 for correct practice and 0 for wrong practice. Which practice was correct and which was wrong was determined according to Slaughterhouse and Meat Inspection Regulation Act 2001 A.D. (2057 B.S.). After that, percentage score of each domain and total domain was calculated. Full marks of domain characteristics were taken as 100 , according to this obtaining less than 25 percent was classified as poor, 25- 50 percent as fair, 50-75 percent as average. Those shops which were obtaining 75-100 percent were classified as good hygiene practice. Inferential statistics were applied to find out association between socio-demographic variables with percentage hygiene score of different domain of meat hygiene practice. Socio-demographic variables were categorical and score on hygiene status were not normally distributed therefore non-parametric Mann-Whitney test and Kruskal Wallis test were used to show the association between selected independent variables (age, education, type of meat, amount of selling, income and training regarding meat hygiene) with the percentage score of 3 domains of meat hygiene. Probability of significance was set at $5 \%$ level of significance.

\section{RESULTS}

Table 1: Socio-demographic Characteristics of Meat Sellers ( $n=125)$

\begin{tabular}{|c|c|c|c|}
\hline Characteristics & Categories & Frequency & Percentage \\
\hline \multirow{5}{*}{ Age in years } & Less than 20 & 4 & 3.2 \\
\hline & $21-40$ & 64 & 51.2 \\
\hline & $41-60$ & 51 & 40.8 \\
\hline & Above 61 & 6 & 4.8 \\
\hline & $\begin{array}{l}\text { Mean } \pm \text { SD }=40.9 \pm \\
12.76, \text { Range } 18-79\end{array}$ & & \\
\hline \multirow{2}{*}{ Sex } & Male & 103 & 82.4 \\
\hline & Female & 22 & 17.6 \\
\hline \multirow{5}{*}{ Caste } & Dalit & 2 & 1.6 \\
\hline & $\begin{array}{l}\text { Disadvantaged } \\
\text { Janajatis }\end{array}$ & 50 & 40.0 \\
\hline & Religious minorities & 8 & 6.4 \\
\hline & $\begin{array}{l}\text { Relatively advantaged } \\
\text { Janajatis }\end{array}$ & 50 & 40.0 \\
\hline & Upper cast groups & 15 & 12.0 \\
\hline \multirow{4}{*}{ Religion } & Hindu & 102 & 81.6 \\
\hline & Buddhist & 7 & 5.6 \\
\hline & Muslim & 8 & 6.4 \\
\hline & Christian & 8 & 6.4 \\
\hline \multirow{5}{*}{$\begin{array}{l}\text { Educational } \\
\text { level }\end{array}$} & Illiterate & 21 & 16.8 \\
\hline & Literate & 20 & 16.0 \\
\hline & Primary & 27 & 21.6 \\
\hline & Secondary & 38 & 30.4 \\
\hline & $\begin{array}{l}\text { Higher secondary and } \\
\text { above }\end{array}$ & 19 & 15.2 \\
\hline \multirow{5}{*}{$\begin{array}{l}\text { Profit in Rs/ } \\
\text { month }\end{array}$} & Less than 10000 & 48 & 38.4 \\
\hline & $11000-20000$ & 48 & 38.4 \\
\hline & 2100030000 & 21 & 16.8 \\
\hline & Above 41000 & 8 & 6.4 \\
\hline & $\begin{array}{l}\text { Mean Rs 17284Range } \\
\text { Rs 2000-150000 }\end{array}$ & & \\
\hline \multirow{4}{*}{ Type of meat } & Mutton & 9 & 7.2 \\
\hline & Pork & 44 & 35.2 \\
\hline & Buff & 20 & 16.0 \\
\hline & Chicken & 52 & 41.6 \\
\hline
\end{tabular}

Half of the respondents (51.2\%) were in age group of 21-40 years. The Mean \pm SD was $40.9 \pm 12.76$ years and range $18-79$ years. Majorities of respondents were male (82.4\%). Equal proportions of respondents were from disadvantaged Janajaties (40\%) and relatively advantaged Janajaties (40\%). Almost two third of the respondents were Hindu (81.6\%). Regarding educational level all educational categoriesilliterate (16.8\%), literate (16\%), primary (21.6\%), higher secondary and above (15.2\%) are nearly equal except secondary (30.4\%). Regarding profit $38.4 \%$ of respondents earn less than 10,000 rupees as equal percentage of respondents earned Rs11000-20000. Regarding the type of meat, nearly half of meat seller sold chicken $(41.6 \%)$, followed by pork (35.2\%).

Table 2: Distribution of Meat Seller on the Basis of Training $(n=125)$

\begin{tabular}{l|l|c|c}
\hline Characteristics & Categories & Frequency & Percentage \\
\hline \multirow{2}{*}{$\begin{array}{l}\text { Training } \\
(n=125)\end{array}$} & No & 87 & 69.6 \\
\hline Yype of training & Hygienic meat cutting and selling & 38 & 30.4 \\
\cline { 2 - 4 }$(n=38)$ & Don't know & 19 & 50.0 \\
\hline
\end{tabular}


It was observed that only $30.4 \%$ of meat seller had taken training on meat hygiene or hygienic slaughtering and selling technique.

\section{Table 3: Terms and Conditions followed by Meat Seller $(n=125)$}

\begin{tabular}{|c|c|c|}
\hline \multirow{2}{*}{ Characteristics } & \multicolumn{2}{|c|}{ Correct Practice } \\
\hline & No. & Percentage \\
\hline Don't spray, sink meat in water or cover with wet cloth & 124 & 99.2 \\
\hline Meat hanged untouched with roof, wall or pillar & 14 & 11.2 \\
\hline Weighing tools untouched with other goods or ground & 59 & 47.2 \\
\hline Chop board cover while not in use & 22 & 17.6 \\
\hline Intestine, abdomen, head, legs, blood untouched with meat & 57 & 45.6 \\
\hline $\begin{array}{l}\text { Don't allow the worker with purulent wounds and } \\
\text { infectious disease }\end{array}$ & 29 & 23.5 \\
\hline $\begin{array}{l}\text { Selling meat of animals free from infection, emaciation, } \\
\text { pregnant and with suckling offspring }\end{array}$ & 71 & 56.8 \\
\hline
\end{tabular}

Practice of using colour, medicine, and chemical in meat, practice of periodic medical examination of staff and practice of meat inspection by meat inspector was not found, almost all meat sellers had not the practice of spraying, sinking meat in water or covering the meat with wet cloth. Nearly half $(47.2 \%)$ of the weighing tools were untouched with other goods or ground. Some (17.6\%) of the meat sellers cover chop board while not in use. In less than half (45.6\%) of the shop intestine, abdomen, head, legs, blood were kept separate from meat, similarly some $(23.5 \%)$ the meat seller involved or allowed worker with purulent wounds and infectious disease to work with meat. More than half (56.8\%) had practice of selling meat of animals free from infection, emaciation, pregnant and suckling offspring.

\section{Table 4: Meat Displaying and Shop Cleaning Practice $(n=125)$}

\begin{tabular}{|c|c|c|c|}
\hline Characteristics & Categories & No. & Percentage \\
\hline \multirow{7}{*}{$\begin{array}{l}\text { Meat display } \\
\text { while selling }\end{array}$} & Aluminum covered wood table & 6 & 4.8 \\
\hline & Packing Sheet on wooden table & 14 & 11.2 \\
\hline & Plastic carpet on wooden/cement slab & 26 & 20.8 \\
\hline & Bamboo/wooden table and hanging & 25 & 20.0 \\
\hline & Cabinet (net/glass) with table & 26 & 20.8 \\
\hline & Refrigerator and marble/ tile slab & 19 & 15.2 \\
\hline & Other & 9 & 7.2 \\
\hline \multirow{5}{*}{$\begin{array}{l}\text { Frequency of } \\
\text { shop cleaning }\end{array}$} & 1 times & 37 & 29.6 \\
\hline & 2 times & 64 & 51.2 \\
\hline & 3 times & 21 & 16.8 \\
\hline & 4 times & 2 & 1.6 \\
\hline & 5 times & 1 & 0.8 \\
\hline \multirow{6}{*}{$\begin{array}{l}\text { Chemical or } \\
\text { detergent use } \\
\text { to clean sales } \\
\text { counter }\end{array}$} & Surf soap water (detergent) & 81 & 64.8 \\
\hline & Packing box sheet change & 14 & 11.2 \\
\hline & Water & 17 & 13.6 \\
\hline & Wet cloth & 7 & 5.6 \\
\hline & Cloth only & 3 & 2.4 \\
\hline & Other & 3 & 2.4 \\
\hline \multirow{5}{*}{$\begin{array}{l}\text { Chemical and } \\
\text { detergent used } \\
\text { to clean the } \\
\text { wall and floor } \\
\text { of the shop }\end{array}$} & Don't clean & 12 & 9.6 \\
\hline & Phenyl water + surf water + kerosene & 14 & 11.2 \\
\hline & Sweep & 67 & 53.6 \\
\hline & Surf water & 13 & 10.4 \\
\hline & Water & 19 & 15.2 \\
\hline
\end{tabular}

Table 4 represents majority (20.8\%) of meat sellers used to display meat on Cabinet (net/glass) with table, similar percentage also display on plastic carpet on wooden cement slab. While selling (19\%) of the meat sellers used to keep meat in refrigerator and marble/tile slab. Half (51.2\%) of the meat seller cleaned the shop two times a day whereas one third (29.6\%) cleaned one time. Regarding type of chemical and detergent used to clean the sales counter, majority (64.8\%) of meat seller used detergent and water, followed by water only (13.6\%), and sheet of packing box change (11.2\%). For cleaning the wall and floor more than half $(53.6 \%)$ of meat seller only swept followed by $15.2 \%$ of them used water only and $11.2 \%$ used phenyl water and surf water / kerosene.

\section{Table 5: Personal Hygiene of Meat Sellers $(n=125)$}

\begin{tabular}{|c|c|c|c|}
\hline Characteristics & Categories & No. & Percentage \\
\hline \multirow{2}{*}{ Finger ring, watches, bracelets } & Yes & 75 & 60.0 \\
\hline & No & 50 & 40.0 \\
\hline Wearing of working cloth & No & 125 & 100.0 \\
\hline \multirow{2}{*}{$\begin{array}{l}\text { Practice of cleaning, disinfection of } \\
\text { hands/tools/clothes after contact with } \\
\text { highly contaminated subjects }\end{array}$} & Yes & 120 & 96.0 \\
\hline & No & 5 & 4.0 \\
\hline \multirow{2}{*}{ If yes, clean by using ( $n=120$ ) } & Water & 48 & 39.4 \\
\hline & Soap water & 72 & 60.4 \\
\hline \multirow{3}{*}{ Hand washing practice } & $\begin{array}{c}\text { Before and } \\
\text { after touching } \\
\text { meat }\end{array}$ & 24 & 19.2 \\
\hline & $\begin{array}{l}\text { After touching } \\
\text { meat }\end{array}$ & 17 & 13.6 \\
\hline & $\begin{array}{l}\text { After finishing } \\
\text { work }\end{array}$ & 84 & 67.2 \\
\hline \multirow{3}{*}{$\begin{array}{l}\text { Body protective material/ device } \\
\text { during meat selling }\end{array}$} & Plastic apron & 15 & 12.0 \\
\hline & Cloth apron & 49 & 39.2 \\
\hline & Don't wear & 61 & 48.8 \\
\hline \multirow{2}{*}{$\begin{array}{l}\text { Practice of cover the wounds by water } \\
\text { tight bandages }\end{array}$} & Yes & 9 & 7.2 \\
\hline & No & 116 & 92.8 \\
\hline $\begin{array}{l}\text { Type of cleaning measures after going } \\
\text { toilet }\end{array}$ & $\begin{array}{l}\text { Hand washing } \\
\text { by soap and } \\
\text { water }\end{array}$ & 125 & 100.0 \\
\hline
\end{tabular}

Regarding personnel hygiene of meat sellers, more than half $(60 \%)$ of meat sellers wore finger ring, watches and bracelets; similarly, they had no practice of wearing working clothes at all. Almost all (96\%) had practice of cleaning, disinfection of hand/tools/clothes after contact with highly contaminated subjects and more than half (57.4\%) used soap water for cleaning followed by water only (38.4\%). Regarding hand washing practice, nearly two third (67.2\%) washed their hands after finishing work, followed by before and after touching of meat (19.2\%). Almost half (48.8\%) of meat seller don't wear body protective material/device during selling of meat, $39.2 \%$ used cloth apron and $12 \%$ of sellers used plastic apron only. Almost all (92.8\%) had no practice to cover the wounds by water tight bandages however all meat sellers had practice of washing their hands with soap and water after going toilet. 
Table 6: Percentage Distribution of Meat Hygiene Practice at Meat Shop $(n=125)$

\begin{tabular}{l|r|r|r|r} 
Categories & $\begin{array}{c}\text { Shop structure } \\
(\%)\end{array}$ & $\begin{array}{c}\text { Terms and } \\
\text { condition (\%) }\end{array}$ & $\begin{array}{c}\text { Personal } \\
\text { hygiene (\%) }\end{array}$ & $\begin{array}{c}\text { Total } \\
\text { hygiene } \\
(\%)\end{array}$ \\
\hline Poor & 23.2 & 38.4 & 2.4 & 26.6 \\
\hline Fair & 52.8 & 48.8 & 83.2 & 58.0 \\
\hline Average & 18.4 & 11.2 & 14.4 & 15.3 \\
\hline Good & 5.6 & 1.6 & 0 & 0 \\
\hline
\end{tabular}

Table 6 presents meat hygiene practice in different domains. In structural status of meat shop, $52.8 \%$ had fair practice but very few (5.6\%) maintained good practice. Almost half $(48.8 \%)$ of them had fair practice in terms and condition for meat handling. In personnel hygiene domain, $83.2 \%$ of the meat seller had fair hygiene but no one maintained good practice.

Overall meat hygiene status of meat shop was not good. More than half (58\%) of the meat shop had fair and only $15 \%$ had average level of hygiene practice.

Table 7: Association of Socio-demographic Variables with domain of Meat Hygiene $(n=125)$

\begin{tabular}{|c|c|c|c|c|c|c|c|}
\hline \multirow{3}{*}{ Characteristics } & \multirow{3}{*}{$\mathbf{N}$} & \multicolumn{6}{|c|}{ Domain of Meat Hygiene } \\
\hline & & \multicolumn{2}{|c|}{$\begin{array}{c}\text { Structure of meat } \\
\text { shop }\end{array}$} & \multicolumn{2}{|c|}{$\begin{array}{c}\text { Terms and } \\
\text { condition for meat } \\
\text { seller }\end{array}$} & \multicolumn{2}{|c|}{ Personnel hygiene } \\
\hline & & Mean \pm SD & $\begin{array}{c}P \\
\text { value }\end{array}$ & Mean \pm SD & $\begin{array}{c}\mathrm{P} \\
\text { value }\end{array}$ & $\begin{array}{l}\text { Mean } \pm \\
\text { SD }\end{array}$ & $\begin{array}{c}P \\
\text { value }\end{array}$ \\
\hline \multicolumn{8}{|l|}{ Age in years } \\
\hline$<20$ & 4 & $44.6 \pm 1.47$ & \multirow{4}{*}{$0.520 *$} & $29.6 \pm 19.3$ & \multirow{4}{*}{$0.633^{*}$} & $42.8 \pm 20.2$ & \multirow{4}{*}{$0.151^{*}$} \\
\hline $21-40$ & 64 & $43.0 \pm 2.03$ & & $36.1 \pm 16.3$ & & $39.2 \pm 12.4$ & \\
\hline $41-60$ & 51 & $38.3 \pm 1.78$ & & $33.4 \pm 15.7$ & & $35.5 \pm 9.2$ & \\
\hline$>61$ & 6 & $35.7 \pm 1.63$ & & $32.2 \pm 17.4$ & & $30.9 \pm 5.8$ & \\
\hline \multicolumn{8}{|l|}{ Educational level } \\
\hline Illiterate & 21 & $39.4 \pm 1.66$ & \multirow{5}{*}{$0.238^{*}$} & $33.6 \pm 12.9$ & \multirow{5}{*}{$0.138^{*}$} & $33.3 \pm 6.9$ & \multirow{5}{*}{$0.001 *$} \\
\hline Literate & 20 & $32.8 \pm 1.36$ & & $30.9 \pm 11.6$ & & $33.5 \pm 8.4$ & \\
\hline Primary & 27 & $41.7 \pm 1.96$ & & $31.4 \pm 18.9$ & & $35.9 \pm 10.8$ & \\
\hline Secondary & 38 & $43.0 \pm 2.16$ & & $38.1 \pm 17.3$ & & $36.8 \pm 10.3$ & \\
\hline $\begin{array}{l}\text { >Higher } \\
\text { secondary }\end{array}$ & 19 & $45.1 \pm 1.94$ & & $37.1 \pm 16.1$ & & $49.6 \pm 13.8$ & \\
\hline \multicolumn{8}{|l|}{ Type of meat } \\
\hline Mutton & 9 & $43.6 \pm 1.76$ & \multirow{4}{*}{$0.001 *$} & $36.1 \pm 6.8$ & \multirow{4}{*}{$0.001^{*}$} & $39.6 \pm 9.5$ & \multirow{4}{*}{$0.143 *$} \\
\hline Pork & 44 & $31.8 \pm 1.39$ & & $21.5 \pm 8.5$ & & $34.7 \pm 9.9$ & \\
\hline Buff & 20 & $38.2 \pm 1.87$ & & $36.2 \pm 11.9$ & & $35.0 \pm 9.8$ & \\
\hline Chicken & 52 & $49.0 \pm 1.98$ & & $44.8 \pm 15.9$ & & $40.3 \pm 12.9$ & \\
\hline \multicolumn{8}{|c|}{ Amount of Meat Sold/day } \\
\hline$<15 \mathrm{~kg}$ & 35 & $42.4 \pm 1.7$ & \multirow{3}{*}{$0.256^{*}$} & $38.7 \pm 12.2$ & \multirow{3}{*}{$0.004^{*}$} & $38.7 \pm 12.7$ & \multirow{3}{*}{$0.699 *$} \\
\hline $16-30 \mathrm{~kg}$ & 30 & $45.2 \pm 2.6$ & & $39.5 \pm 18.5$ & & $39.0 \pm 12.9$ & \\
\hline $31-45 \mathrm{~kg}$ & 18 & $40.8 \pm 17.2$ & & $28.8 \pm 14.8$ & & $37.3 \pm 11.1$ & \\
\hline
\end{tabular}


Type of meat was highly significant with structure of meat shop $(p=<0.001)$. There was significant association between education level of the meat seller with personnel hygiene $(p=<0.001)$. Mean hygiene score of personal hygiene domain was found to be increased according to the level of education. The study also found that the type of meat sold $(p=<0.001)$ and amount of meat sold per day $(p=<0.004)$ was significantly associated with terms and conditions followed by meat seller.

Table 7 shows that there was significant association between terms and condition $(p=<0.002)$ and personnel hygiene $(p=<0.029)$ with profit of meat seller. Similarly mean score of the hygiene was found high where profit earned was more than Rs. 31000.

\section{DISCUSSION}

Although zoonoses and meat borne infection is preventable, lack of awareness about zoonoses and meat borne infection, poor SIMA implementation have made it a major public health problem in developing countries. In this study most of the meat shop did not meet the structural requirement and minimum basic facilities according to Slaughterhouse and Meat Inspection Regulation Act (SIMA) 2001 AD. The legal provisions against person who don't meet the criteria is to pay fine of five thousand (NPR) for the first time and ten thousand for every next time or one-month imprisonment, or both. But there was no evidence of such punishment and not any of the shop meet all the criteria. ${ }^{11}$ Practice of ante-mortem and postmortem examination of animals/ carcass was not found as well as separate slaughterhouse was not made but the butchers had felt need of slaughterhouse. Another study conducted by Joshi in Kirtipur municipality found no pre and post mortem meat inspection and slaughterhouse examination by any government authority. ${ }^{9}$ The study conducted in Dharan municipality in 2012 supported the present study that no ante-mortem inspection of animals and post-mortem inspection of carcass/meat and viscera were carried out. Similarly, $48.39 \%$ of the butchers felt the necessity of slaughterhouse. ${ }^{5}$

This study shows butcher had no practice of periodic medical examination of self as well as staffs, $43 \%$ butcher had practice of selling meat of infectious, emaciation, pregnant animals and with suckling offspring. Practice of meat inspection by meat inspector was not found, similarly almost two third of the meat seller are involved or allowed worker with purulent wounds and infectious disease to work with meat. All these factors contribute to contaminate meat and may cause meat borne infection and intoxication.

Another study conducted previously in same setting found that around $16 \%$ of the butchers clean their shops 2-4 times only in a week. Further $74.12 \%$ of the shops used water for cleaning, $22.58 \%$ used soap or detergent powder as sanitizing agent. From the survey, $16.13 \%$ of the shops atmosphere was found dirty. ${ }^{5}$ About half (51.2\%) of the meat seller cleaned the shop 2 times a day, further $64.8 \%$ of the meat seller used soap or detergent powder as sanitizing agent. This study showed practice was better in the present study compared to previous study. This contradiction may be due to study sample. Previous study conducted among buff meat shop whereas in this study only $16 \%$ were buffalo meat seller. In general, more hygienic practices found in mutton and chicken slaughtering and selling place than buffalo slaughtering and selling.

This study found that, meat seller had no practice of wearing working clothes at all. Nearly half of meat seller didn't wear (48.8\%) anything as body protective material/device during selling of meat followed by $39.2 \%$ wore cloth apron and $12 \%$ of them wore plastic apron only. More than half (60\%) of meat seller wore finger ring, watches and bracelets. Another study conducted in Ethiopia also supports these findings, among the 71 butcher shop workers, $11.3 \%$ of them did not use protective clothes and $50.7 \%$ did not cover their hair. $47.9 \%$ of the butchers handled money while serving food and $78.9 \%$ of them had worn jewellery materials. ${ }^{10}$ Study conducted in Chitwan among pig meat seller also supports this study. ${ }^{3}$ Another study showed that $14.6 \%$ of the abattoir workers did not wear aprons and they all handled food with their bare hands. ${ }^{10}$

In Dharan, almost all meat sellers (96\%) had practice of cleaning, disinfection of hand/tools/clothes after contact with highly contaminated subjects and majorities (57.4\%) of them used soap water for cleaning. Only $19.2 \%$ had practice of washing hands before and after touching of meat. They also answered that more than half (67.2\%) washed their hands after finishing work only. During survey it was found that meat seller had practice of handling money, touching other objects, drinking fluids and eating dry foods as well as selling of meat without washing their hands so that meat handlers are probable sources of contamination for microorganisms. Almost all (92.8\%) had no practice to cover the wounds by water tight bandages so human blood, body fluid and microorganism easily transmits to the fresh meats. All meat sellers had practice of washing their hands with soap and water after going toilet.

Study found that education was highly significant $(p=<0.001)$ with slaughtering practice and personnel hygiene $(p=<0.001)$ of the meat seller. Mean score of hygiene of all domain was found to be increased along with the level of education. Study conducted among pig meat seller in Chitwan also supports this study that the hygienic practices like sanitation of equipments' and regular washing of hands were significantly associated ( $p=<0.05)$ with level of education. ${ }^{3}$

There was significant association between type of meat and structure of meat shop $(p=<0.001)$. Mean hygiene score of chicken and mutton was higher in all domains than pork and buff it may be due to size of animals which may affect slaughtering practices. Significant association $(p=<0.002)$ 
was found between profit earned and terms, condition followed by meat seller, it may be due to increase in income level automatically changes in practice.

The study result conducted by Adhikari BM, support the unhygienic meat selling practice of Dharan. Buffalo meat of local market can be said to be heavily contaminated with spoilage and pathogenic organisms, due to unhygienic slaughtering and handling conditions. ${ }^{5}$

Above all findings found that lack of ante-mortem postmortem examination and poor handling practice of meat in Dharan. Although the impact of meat -borne diseases has been least detected because of thorough cooking, the nutrient loss in meat due to the contaminating pathogens and microorganisms cannot be compensated. Also some diseases may eventually be passed on to staffs working in the slaughter-sites or meat shops and those involved in handling such meat.

Department of Livestock Services (DLS) have major responsibilities for the implementation and enforcement of Animal Slaughterhouse \& Meat Inspection Act 1999 and Animal Slaughterhouse \& Meat Inspection Regulation 2001 as well as local municipalities are the first level of local governance, responsible for proper management of all the sector. ${ }^{11}$ Lack of poor Act implementation by the responsible body was the example of current meat business of Dharan. Local Meat organization are demanding well facilitated slaughterhouse and some support from government should be provided to manage the meat business before strict implementation of act. So the responsible authorities meat sellers and public should jointly make effort to improve this sector.

\section{REFERENCE}

1. WHO. The Control of Neglected Zoonotic Diseases A route to poverty alleviation [Internet]. Geneva; 2006. Available from: http://www.who.int/zoonoses/Report_Sept06.pdf

2. Mann I. WHO Guidelines for sloughterhouse in developing countries and.pdf. Geneva, Switzerland: Veterinary Public Health Unit, Division of Communicable Disease; 1984;5-103. Available from: http://www.who.int/iris/handle/10665/66404

3. Ghimire L, Dhakal S, Pandeya YR, Chaulagain S, Mahato BR, Satyal RC SD. Assessment of pork handlers ' knowledge and hygienic status of pig meat shops of Chitwan district focusing campylobacteriosis risk factors. Int J Infect Microbiol [Internet]. 2013;2(1):17-21. Available from: http://doi.dx.org/10.3126/ijim.v2i1.8004 OR www.nepjol.info/index.php/IJIM/article/download/8004/6515

4. Joshi DD, Maharjan M, Johnsen MV, Willingham AL, Gaihr Y SM. Taeniasis / Cysticercosis Situation in Nepal. Southeast Asian J Trop Med Public Heal [Internet]. 2004;35(Suppl 1):252-8. Available from: http://www.tm.mahidol.ac.th/seameo/2004-35-suppl-1/45-252.pdf

5. Adhikari BM, Subedi RP SD. A Study on Standard of Buffalo Meat Hygiene in Dharan. J Food Sci Technololy Nepal, [Internet]. 2012;7(1979):5-8. Available from: http://www.nepjol.info/ index.php/JFSTN/article/view/10617

6. Medical record section. B. P. Koirala Institute of Health Sciences, Dharan; 2013. (Unpublished data)

\section{CONCLUSION}

The study concludes that hygiene practice of all the meat shop in Dharan municipality is not satisfactory. Most of the criteria set by authorities remain unmet. Few meat shops are maintaining the scientific handling and hygienic practice. Study revealed that education and type of meat are significantly associated with meat hygiene practice. Concern authorities should be aware to improve the quality of meat hygiene practice.

\section{RECOMMENDATION}

Similar study can be carried out in different area in large setting. Microbiological analysis of the raw meat can be done to find out the type of microorganism. Interventional study providing awareness package regarding meat-borne diseases, zoonoses diseases can be done among consumer and meat seller. Effort should be made by the policy makers to establish modern slaughtering places and selling places with all the facilities needed.

\section{LIMITATION OF THE STUDY}

This study is limited to observation of meat shop and subjective responses given by meat seller regarding hygienic meat cutting and selling. This study was only focused on Dharan. So that it may not be suitable to other city.

\section{ACKNOWLEDGMENT}

The authors would like to thank the staffs of Dharan Submetropolitan city Office, the owner of butcher shop, local meat organization for their interest and participation shown in study.

\section{CONFLICT OF INTEREST}

The authors declare that no competing interest exists and no specific funding received for this study, for preparation of manuscript and for publication. Total expenditure has been bore by first author.

7. Karna VK. Implementation Status of SMIA ( Slaughterhouse \& Meat Inspection Act ) ( 1999 ) in Kathmandu [Internet]. North South University, Bangladesh; 2010. Available from: http://www.mppgnsu.org/attachments/119_Karna_Thesis.pdf

8. Joshi DD, Maharjan M, Johansen MV, Willingham AL SM. Improving meat inspection and control in resource-poor communities: the Nepal example. Acta Trop [Internet]. 2003 Jun [cited 2013 Jun 18];87(1):119-27. Available from: http://linkinghub.elsevier.com /retrieve/pii/S0001706X03000287

9. Joshi DD. Zoonoses and Food Hygiene News. Natl Zoonoses Food Hyg Res Cent [Internet]. Kathmandu; 2009;15(2):1-2. Available from: http://nzfhrc.org.np/wp-content/uploads/2016/08/V15N2.pdf

10. Haileselassie M, Taddele $H$, Adhana K KS. safety knowledge and practices of abattoir and butchery shops and the microbial profile of meat in $\mathrm{M}$ ekelle $\mathrm{C}$ ity , E thiopia F ood. Asian Pac J Trop Biomed [Internet]. 2013;3(5):407-12. Available from: www.elsevier. com /locate /apjtb OR https://www.ncbi.nlm.nih.gov/pmc/articles/PMC3642452.

11. Animal Slaughterhouse and Meat Inspection Act, 2055(1999). Nepal. Available from: www.lawcommission.gov.np Or http://www.spsenquiry.gov.np/downloadfile/animalslaughterhouse-and-meat-inspection-act. 